Article

\title{
Dramatic Influence of Ionic Liquid and Ultrasound Irradiation on the Electrophilic Sulfinylation of Aromatic Compounds by Sulfinic Esters
}

\author{
Ngoc-Lan Thi Nguyen ${ }^{1}$, Hong-Thom Vo ${ }^{1}$, Fritz Duus ${ }^{2}$ and Thi Xuan Thi Luu ${ }^{1, *}$ \\ 1 Department of Organic Chemistry, VNUHCM-University of Science, 227 Nguyen Van Cu St., Dist. 5, \\ 700000 Ho Chi Minh City, Vietnam; lanbmt07@gmail.com (N.-L.T.N.); hongthom2012@gmail.com (H.-T.V.) \\ 2 Department of Science and Environment, Roskilde University, P.O. Box 260, DK-4000 Roskilde, Denmark; \\ fd@ruc.dk \\ * Correspondence: 1txthi@hcmus.edu.vn; Tel.: +84-0208-3835-3193
}

Received: 12 August 2017; Accepted: 28 August 2017; Published: 4 September 2017

\begin{abstract}
The sulfinylation reaction of aromatic and hetero-aromatic compounds with sulfinic esters as electrophiles has been investigated in different ionic liquids and by means of different Lewis acid salts in order to get moderate to good yields of asymmetrical sulfoxides. Mixtures of 1-butyl-3-methylimidazolium chloride and aluminum chloride were found to be the most efficient and recyclable reaction framework. Ultrasound sonication appeared to be the most useful and green activation method to afford the sulfoxides in yields better than or equivalent to those obtained under the longer-lasting conventional stirring conditions.
\end{abstract}

Keywords: Friedel-Crafts sulfinylation; sulfinic ester; synthesis of sulfoxide; ultrasound irradiation; chloroaluminate-based ionic liquid

\section{Introduction}

Sulfoxides are important intermediates in organosulfur chemistry, especially in the syntheses of drugs and sulfur-containing natural products [1]. Sulfoxides are also used as cardiotonic agents [2], psychotonics [3,4], vasodilators [5], and therapeutic agents for anti-ulcer (proton pump inhibitor) [6-12], antibacteria, antifungi, or anti-atherosclerosis [13-17], and antihypertension [18].

The importance of sulfoxides in organic syntheses has attracted the attention of chemists to find new methodologies for sulfoxide synthesis. Aliphatic and aromatic sulfoxides have been prepared by the direct and popular oxidation of thioethers [19,20], by indirect reduction of sulfones [21], or by nucleophillic interaction of Grignard reagents on sulfinic esters [22,23], and sulfoxides [24].

Symmetrical aromatic sulfoxides can also be obtained by reaction of arenes with thionyl chloride [25,26], as well as symmetrical/asymmetrical aromatic sulfoxides can be prepared by sulfinylation of aromatic compounds, as described aldready in 1926 [27]. More than thirty years later, alkanesulfinylation and arenesulfinylation of aromatic compounds, (e.g., benzene, azulene/guaiazulene, substituted phenols, and aniline derivatives) with alkanesulfinyl or arenesulfinyl chlorides as electrophiles were investigated in the presence of pyridine [28], anhydrous aluminium chloride [29-31], as well as $\mathrm{SnCl}_{4}$ or $\mathrm{SbCl}_{5}$ [30]; however, owing to the easy decomposition of the sulfinyl halides, harsh reaction conditions were required [28-30]. Very recently a replacement of the sulfinyl halides by more stable electrophiles, i.e., sulfinic esters, was introduced in 2011 by Yuste et al. [32]. In connection with the synthesis of (phenylsulfinyl)phenols, the Thia-Fries rearrangement of aryl benzenesulfinate in the presence of aluminum chloride has been studied [33].

The ionic liquid ethylammonium nitrate was synthesized already in the early 1910s [34]. Subsequently, research and development of ionic liquid has concentrated mainly on electrochemical 
applications since 1948 [35]. In the early 1980s ionic liquids (ILs) attained much more attention owing to their unique chemical and physical properties of non-volatility, non-flammability, thermal stability, and controlled miscibility $[35,36]$. They have been also used as green solvents in various biphasic ILs-transition metal-catalyzed organic reactions in order to improve catalyst storage, handling, recycling and reuse. The first successful combination of an ionic liquid, dialkylimidazolium chloride, with aluminum chloride used as a Lewis acid catalyst in Friedel-Crafts acylations was reported in 1986 [37].

One of viewpoints on green chemistry, ultrasound irradiation has been regarded as a clean and useful protocol during the last three decades in comparison with traditional activation methods. Many categories of homogeneous or heterogeneous reactions accelerated by ultrasound irradiation have been launched in order to reduce the reaction time, and generate fewer byproducts and a higher yield of the main product $[38,39]$.

In this present work, we integrate the advantages of ultrasound irradiation accelerated sulfinylation of arenes and hetero-arenes with stable alkyl alkanesulfinates/arenesulfinates in the presence of different acidic catalysts to produce asymmetrical sulfoxides (Scheme 1). Several Lewis acid salts as well as a task-specific ionic liquid and the mixtures of 1-butyl-3-methyl-imidazolium chloride and different Lewis acid salts with different Lewis acidity were investigated.

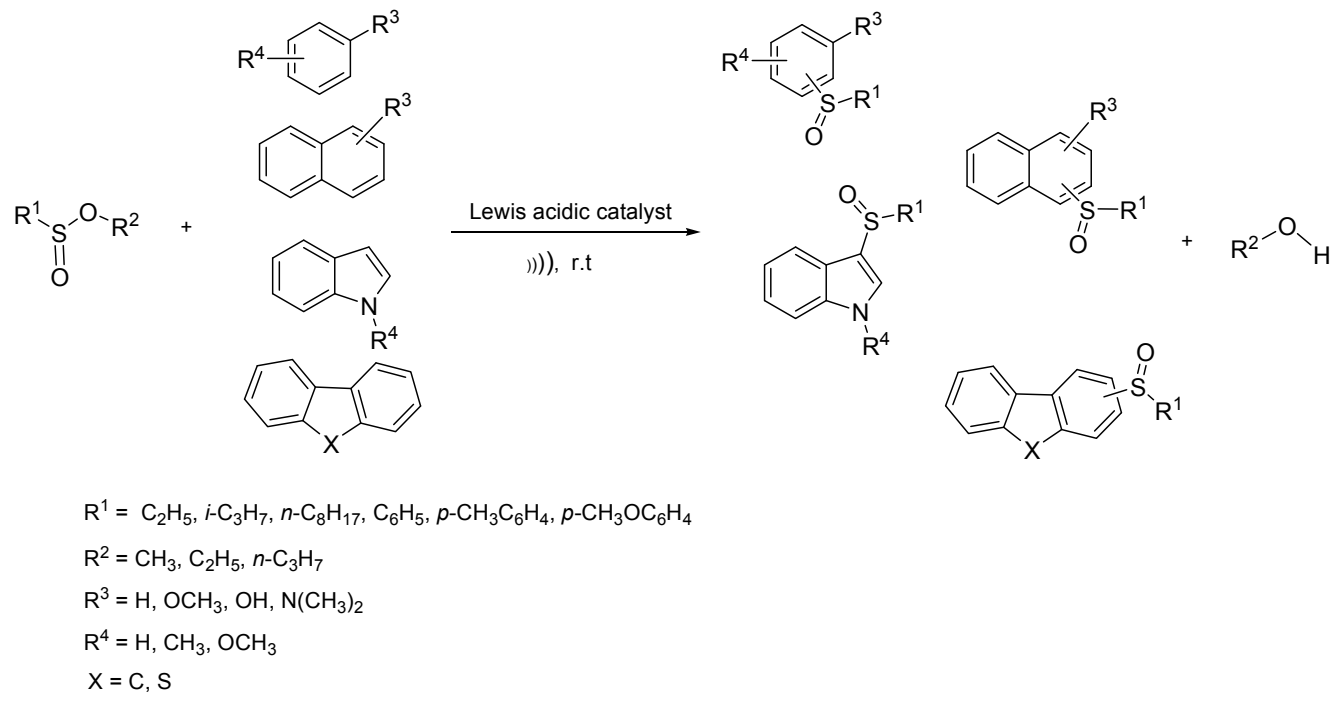

Scheme 1. Synthesis of sulfoxides from alkyl alkanesulfinate/arenesulfinate via the sulfinylation reaction.

\section{Results}

Based on the previous literature and the points of view on green chemistry, a series of Lewis acid salts, for instance bismuth(III) triflate, lanthanide(III) triflate, and copper(II) triflate were used as the acidic catalysts for the solvent-free sulfinylation of 1,3-dimethoxybenzene (our arbitrarily-chosen model substrate) by methyl benzenesulfinate under ultrasound irradiation in order to compare with aluminum chloride catalyst (Entries 1-4, Table 1). The results showed that aluminum chloride efficiently catalyzed the sulfinylation of 1,3-dimethoxybenzene into 2,4-dimethoxy-1-(phenylsulfinyl)benzene under solvent-free as well as solvent reaction condition (Entry 5, Table 1); however, the product selectivity of 2,4-dimethoxy-1-(phenylsulfinyl)benzene reported by GC/MS analyses was achieved $60 \%$ from the solvent-free sulfinylation lower than $88 \%$ from the solvent sulfinylation owing to severe demethylation of methoxy substituent on aromatic ring. In addition, it is not safe to add anhydrous aluminum chloride directly into the reaction mixture due to the large exotherm.

On the way to find out a green and recyclable acidic catalyst, a series of ionic liquids (Entries -6-12, Table 1), e.g., a task-specific ionic liquid, 1-methyl-3-(4-sulfobutyl)imidazolium hydrogen sulfate, 
$\left[\left(\mathrm{HSO}_{3}\right)^{4} \mathrm{C}_{4} \mathrm{C}_{1} \mathrm{Im}\right] \mathrm{HSO}_{4}$, an eutectic mixture of choline chloride and zinc chloride as well as the mixture of $[\mathrm{Bmim}] \mathrm{Cl}$ and several Lewis acid salts were investigated. The results substantiate our choice of chloroaluminate-based 1-butyl-3-methylimidazole chloride as the most efficient catalyst under ultrasound irradiation. Owing to the mild and efficient catalysis of chloroaluminate-based 1-butyl-3-methylimidazole chloride, demethylation of methoxy substituted group was not found by GC/MS analyses and thin layer chromatography (TLC) during the reaction period.

The composition of chloroaluminate-based ionic liquids is expressed as the apparent $\mathrm{AlCl}_{3}$ mole fraction $(\mathrm{N})$ in order to vary their Lewis acidity. They are classified into three types such as base liquids, neutral liquids and acidic liquids [37,40]. Further experiments on the $\mathrm{AlCl}_{3}$ mole fraction (Entries 12-14, Table 1) demonstrated that $[\mathrm{Bmim}] \mathrm{Cl} \cdot 2 \mathrm{AlCl}_{3}$ or $[\mathrm{Bmim}]\left[\mathrm{Al}_{2} \mathrm{Cl}_{7}\right]$ (1-butyl-3-methylimmidazole combined with twice molar amount of aluminum chloride, $\mathrm{N}=0.67$ ) promoted the sulfinylation of 1,3-dimethoxybenzene to take place most efficiently.

Table 1. Influence of the nature of the acidic catalyst on the formation of 2,4-dimethoxy-1(phenylsulfinyl)benzene (3a) ${ }^{a}$.

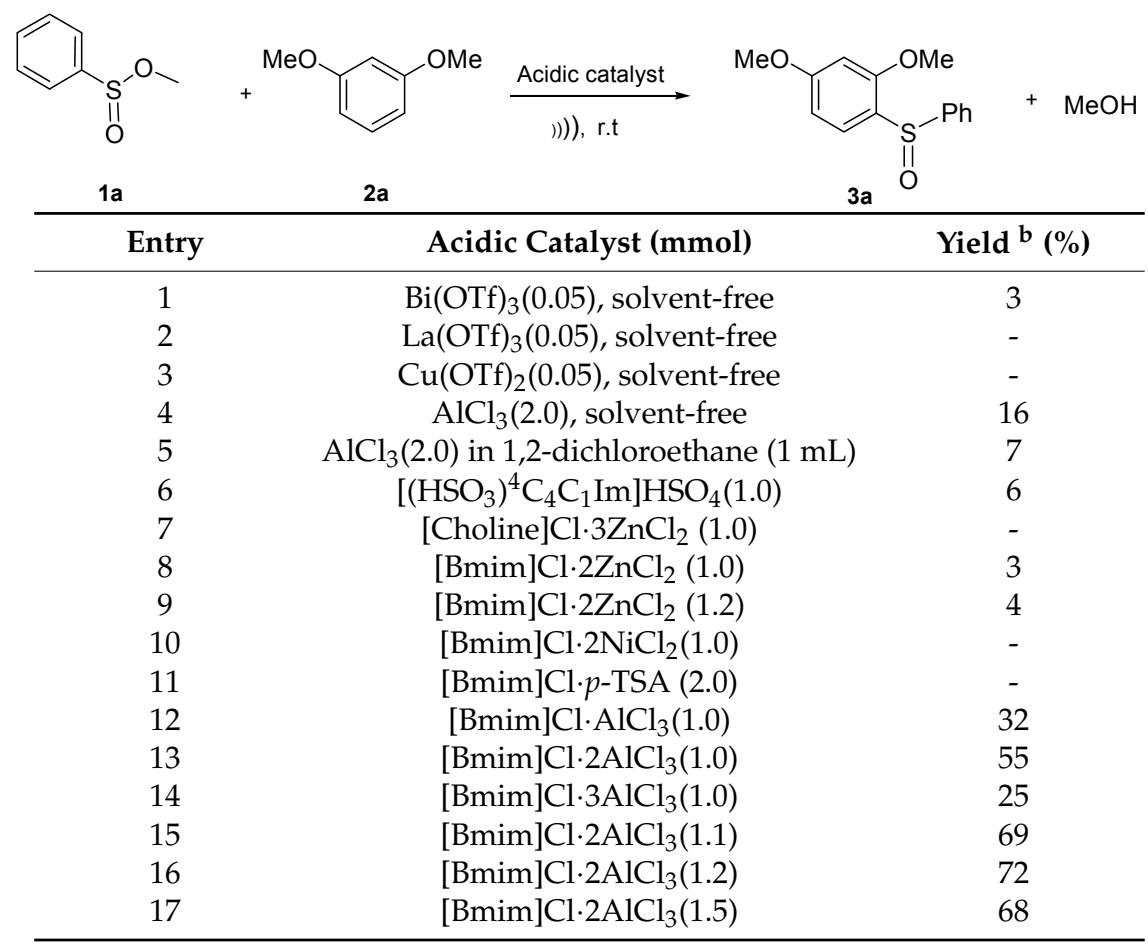

a The reactions of 1,3-dimethoxybenzene $(1 \mathrm{mmol})$ with methyl benzenesulfinate $(1 \mathrm{mmol})$ catalyzed by the acidic catalysts were performed under ultrasound irradiation for one hour at room temperature; ${ }^{b}$ Yield of isolated product.

In order to improve the reaction conversion and yield of sulfoxide, the molar ratio of [Bmim $] \mathrm{Cl} \cdot 2 \mathrm{AlCl}_{3}, 1,3$-dimethoxybenzene, methyl benzenesulfinate was investigated (Entries 15-17, Table 1). Subsequently, the other reaction factors consisting of reaction temperatures (e.g., room temperature, $50^{\circ} \mathrm{C}$ and $60^{\circ} \mathrm{C}$ ), the reaction time, and the activation methods (e.g., magnetic stirring, ultrasound irradiation and microwave irradiation) were also studied. Consequently, the most efficient procedure for the sulfinylation of 1,3-dimethoxybenzene $(1 \mathrm{mmol})$ with methyl benzenesulfinate $(1 \mathrm{mmol})$ in the appropriate amount of $[\mathrm{Bmim}] \mathrm{Cl} \cdot 2 \mathrm{AlCl}_{3}(1.2 \mathrm{mmol})$ performed under ultrasound irradiation for one-hour at room temperature was selected (Entry 1, Table 2). Further experiments showed that the highest yield of 2,4-dimethoxy-1-(phenylsulfinyl)benzene was achieved up to 72\% after one-hour ultrasound irradiation, while it was $69 \%$ after four-hour magnetic stirring. In addition, microwave irradiation is not an efficient method for this reaction owing to the decomposition of reaction mixture at warm temperature (approx. $50^{\circ} \mathrm{C}$ ). 
The optimized conditions were used to investigate the substrate scope of the sulfinylation. Altogether ten aromatic and hetero-aromatic compounds were subjected to $[\mathrm{Bmim}] \mathrm{Cl} \cdot 2 \mathrm{AlCl}_{3}$-catalysed electrophilic sulfinylation by eight alkyl alkanesulfinate/arenesulfinates under ultrasound irradiation (Tables 2 and 3).

Table 2. Influence of the nature of the alkyl alkane/arenesulfinates on the yields of asymmetrical sulfoxides ${ }^{\mathrm{a}}$.

Entry

\footnotetext{
a The reactions of 1,3-dimethoxybenzene $(1 \mathrm{mmol})$ with sulfinic ester $(1 \mathrm{mmol})$ catalyzed by $[\mathrm{Bmim}]\left[\mathrm{Al}_{2} \mathrm{Cl}_{7}\right]$

$(1.2 \mathrm{mmol})$ were performed under ultrasound irradiation for a specific period of time (in hours) at room temperature;

b Yield of isolated product.
}

The results from altering eight alkyl alkanesulfinate/arenesulfinates used for the sulfinylation of 1,3-dimethoxybenzene demonstrated that the structures of sulfinic esters have influenced the reaction conversion and yield significantly (Table 2). Alkyl arenesulfinates appeared as better electrophiles than alkyl alkanesulfinates. It was, therefore, concluded that the aromatic ring played an important role to stabilize electrons of intermediate in the transition stage (Discussion, Scheme 2). 
Table 3. Influence of the nature of the aromatic compounds on the sulfinylation using methyl benzenesulfinate ${ }^{\mathrm{a}}$.

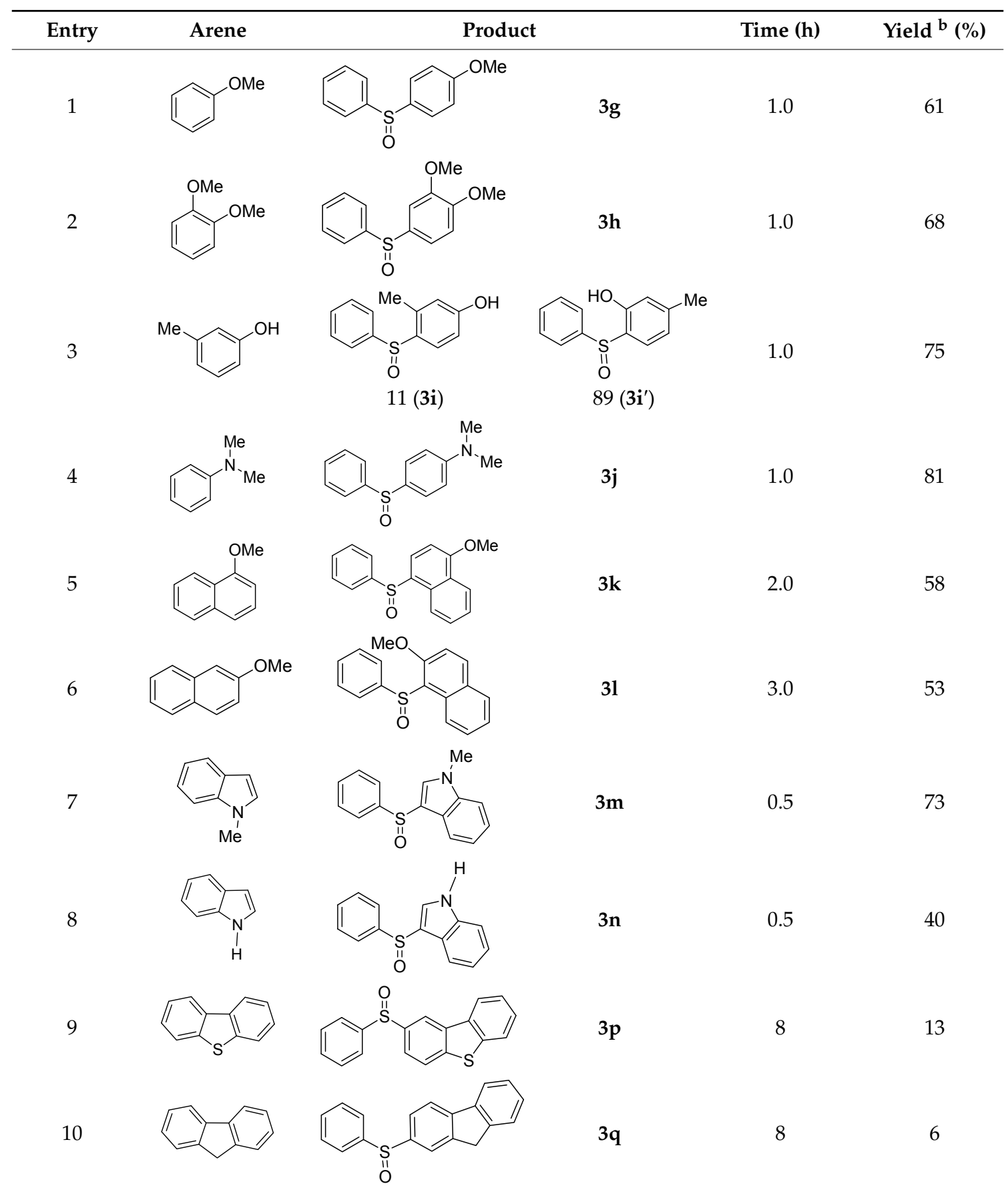

${ }^{\text {a }}$ The reactions of arene $(1 \mathrm{mmol})$ with methyl benzenesulfinate $(1 \mathrm{mmol})$ catalyzed by [ $\left.\mathrm{Bmim}\right]\left[\mathrm{Al}_{2} \mathrm{Cl}_{7}\right](1.2 \mathrm{mmol})$ were performed under ultrasound irradiation for a specific period of time (in hours) at room temperature; ${ }^{b}$ Yield of isolated product. 


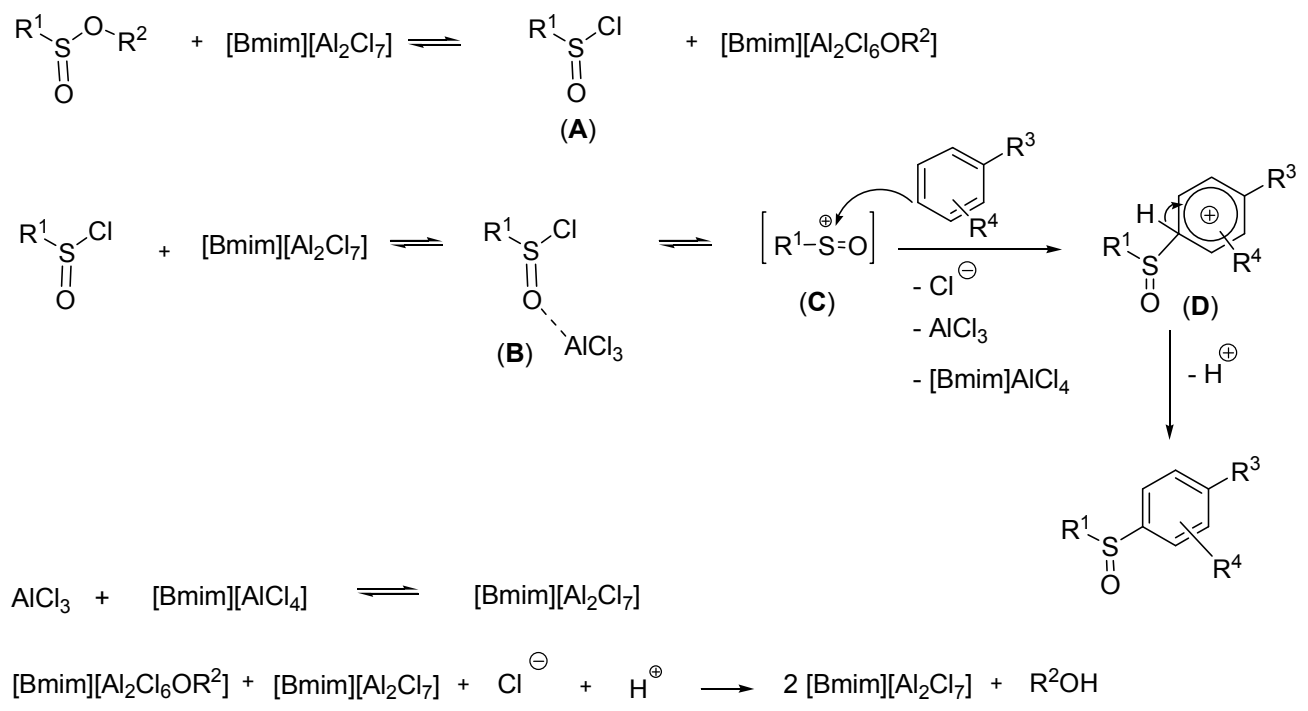

Scheme 2. A plausible mechanism for the sulfinylation of aromatic compounds with alkyl arenesulfinates using $[\mathrm{Bmim}]\left[\mathrm{Al}_{2} \mathrm{Cl}_{7}\right]$.

In the next series of experiments on the influences of substituted benzene or substituted polycyclic benzenoid hydrocarbons, benzene, naphthalene and phenanthrene were selected as model substrates. The results displayed that the reactions of benzene and naphthalene with methyl benzenesulfinate did not occur, while the reaction of phenanthrene worked slowly to obtain a low yield of sulfoxide $(4 \%)$ under ultrasound irradiation for three hours. Further experiments on the electrophilic sulfinylation of electron rich arenes with methyl benzenesulfinate demonstrated that sulfoxide products were obtained in moderate to good yield after much shorter reaction times (generally $1 \mathrm{~h}$ ) under ultrasound irradiation, especially most sulfinyl groups were predominantly located at para position compared with the former activating substituents on aromatic substrates in order to reduce the steric hindrance (Entries 1-6, Table 3). Contrarily, a sulfinyl group was favorably occupied at the ortho position compared with hydroxyl group in order to reach a lower transition free energy and more stable product from the formation of intra-hydrogen bond between hydroxyl group and sulfinyl group (Entry 3, Table 3).

In the continuation of substrate investigation, the reactions of indole derivatives and methyl benzenesulfinate showed that the amount of sulfoxide formed from the sulfinylation of indole was obtained in a lower yield than it from the sulfinylation of 1-methylindole due to a complex formation between indole and [ $\mathrm{Bmim}]\left[\mathrm{Al}_{2} \mathrm{Cl}_{7}\right]$ (Entries 7 and 8, Table 3).

With advantages of $[\mathrm{Bmim}]\left[\mathrm{Al}_{2} \mathrm{Cl}_{7}\right]$ on enhanced reactivity and mildness, the reusability of [Bmim] $\left[\mathrm{Al}_{2} \mathrm{Cl}_{7}\right]$ was focused on for examination. The $[\mathrm{Bmim}]\left[\mathrm{Al}_{2} \mathrm{Cl}_{7}\right]$ collected after separation from the previous reactions was washed with diethyl ether, subsequently evaporated under reduced pressure at $80{ }^{\circ} \mathrm{C}$ for $30 \mathrm{~min}$ and obtained in $82 \%$ of recycled yield. The structure of recovered catalyst at the fourth recycle time was comparable with that of the fresh $[\mathrm{Bmim}]\left[\mathrm{Al}_{2} \mathrm{Cl}_{7}\right]$ by ${ }^{1} \mathrm{H}-\mathrm{NMR}$ spectra. The recycled $[\mathrm{Bmim}]\left[\mathrm{Al}_{2} \mathrm{Cl}_{7}\right]$ was used for the sulfinylation of 1,3-dimethoxybezene with methyl benzenesulfinate as that of the optimized experiment presented in Entry 1, Table 2. The catalytic efficiency of $[\mathrm{Bmim}]\left[\mathrm{Al}_{2} \mathrm{Cl}_{7}\right]$ did not drop significantly even after three runs of being reused and recycled (Figure 1). 


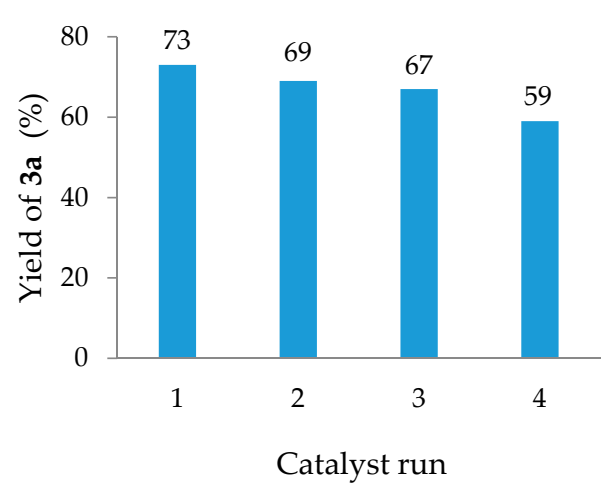

Figure 1. Reusability of [Bmim] $\left[\mathrm{Al}_{2} \mathrm{Cl}_{7}\right](1.2 \mathrm{mmol})$ in the sulfinylation of 1,3-dimethoxybenzene $(1 \mathrm{mmol})$ with methyl benzenesulfinate $(1 \mathrm{mmol})$ under one-hour of ultrasound irradiation.

\section{Discussion}

According to several previous investigations on the formation of arenesulfinyl chloride intermediates occurred reversibly from the corresponding alkyl arenesulfinates in the presence of hydrogen chloride and chloride ions [41], arenesulfinyl chlorides (A) are obviously generated and preserved under chloroaluminate-based 1-butyl-3-methylimidazole chloride $(\mathrm{N}=0.67)$ owing to a large number of chloride ions. Subsequently, the formation of sulfoxide can be explained by a mechanism similar to that of the Friedel-Crafts sulfonylation of arenes [42], and the sulfenylation of indole [43]. It meant that a complex (B) of arenesulfinyl chloride with $\mathrm{AlCl}_{3}$ in $[\mathrm{Bmim}]\left[\mathrm{Al}_{2} \mathrm{Cl}_{7}\right]$ was formed and then released sulfinyl cation (C) which was efficiently stabilized by delocalized electrons of benzene. After that, an intermediate (D) could be produced by an eletrophilic sulfinylation of electron rich arenes with sulfinyl cation. Finally, a loss of a proton from (D) produced the sulfoxide product (Scheme 2).

\section{Materials and Methods}

\subsection{Instrumentation}

Microwave irradiation was performed by means of a CEM Discover microwave oven produced by CEM Corporation, Matthews, NC, USA. Ultrasound irradiation was performed by means of a BRANSON 1510 ultrasonic bath, operating at $40 \mathrm{kHz}$ with a power output of $70 \mathrm{~W}$. GC/MS analyses were performed on a Hewlett Packard 6890 GC series II, apparatus of MS 5975C with a triple-axis detector equipped with a J and W DB-5MS capillary column ( $30 \mathrm{~m}, 0.25 \mathrm{~mm}$ i.d., $0.25 \mu \mathrm{m}$ film thickness) and a Hewlett Packard 7683B autosampler. LC/MS analyses were performed on a micrOTOF-QII-ESI-Qq-TOF (Bruker Daltonics, Bremen, Germany) with UV/VIS and MS detector, the heated capillary of iron trap mass spectrometer was set to $350{ }^{\circ} \mathrm{C}$, reverse column ACE $3 \mathrm{C} 18$ $(5 \mu \mathrm{m} \times 4.6 \times 150 \mathrm{~mm})$ and ESI (electrospray ionization): $\mu$ QTOF Bruker. NMR spectra were recorded on a Brüker $500 \mathrm{NMR}$ spectrometer at $500 \mathrm{MHz}\left({ }^{1} \mathrm{H}\right)$ and $125 \mathrm{MHz}\left({ }^{13} \mathrm{C}\right)$.

\subsection{Chemicals}

All commercially available chemicals used were from Aldrich and analyzed for authenticity and purity by GC/MS before being used.

Preparation of commercially unavailable alkyl alkanesulfinates/arenesulfinates: A solution of $\mathrm{N}$-bromosuccinimide $(6 \mathrm{mmol}, 1.067 \mathrm{~g})$ dissolved in methanol $(5 \mathrm{~mL})$ and ethyl acetate $(1 \mathrm{~mL})$ was added dropwise into the $25 \mathrm{~mL}$ two-neck round-bottom flask already containing thiol $(3 \mathrm{mmol})$ in methanol $(5 \mathrm{~mL})$, and then $4 \mathrm{~mL}$ of methanol was poured additionally up to $14 \mathrm{~mL}$ total amount. The flask was placed into an ultrasound bath where the mixture of reactants was exposed to ultrasound irradiation for a specific period of time. Subsequently, the reaction mixture was extracted with dichloromethane $(4 \times 15 \mathrm{~mL})$. The combined extracts were neutralized with a saturated solution of 
$\mathrm{NaHCO}_{3}$, washed with water until neutral, and then dried by anhydrous $\mathrm{Na}_{2} \mathrm{SO}_{4}$. After removal of the solvent by rotary evaporation, the remaining crude product was analyzed by GC/MS and purified by column chromatography using eluent as a mixture of $n$-hexane and dichloromethane $(6: 4 \mathrm{v} / \mathrm{v})$. The identity and purity of all sulfinic esters obtained were confirmed by ${ }^{1} \mathrm{H}-\mathrm{NMR},{ }^{13} \mathrm{C}-\mathrm{NMR}$ and GC/MS to make sure purity $>99 \%$ (according to analysis by GC/MS) [44].

Preparation of [Bmim]Cl-2AlCl 3 : An amount of 1-methylimidazole (10 mmol, $1.745 \mathrm{~g})$ and $n$-butyl chloride ( $11 \mathrm{mmol}, 1.018 \mathrm{~g}$ ) were sequentially added into a $25 \mathrm{~mL}$ round-bottom flask assembled with the condenser. The reaction mixture was stirred magnetically with $250 \mathrm{rpm}$ speed at $60-65{ }^{\circ} \mathrm{C}$ for $24 \mathrm{~h}$. After cooling down to room temperature, the reaction mixture was washed with diethyl ether $(5 \times 10 \mathrm{~mL})$ until no trace of $n$-butyl chloride, as well as 1-methylimidazole in a solution of diethyl ether were detected by thin layer chromatography (TLC) and gas chromatography (GC). The other solution containing recyclable [Bmim] $\mathrm{Cl}$ was evaporated under reduced pressure at $80^{\circ} \mathrm{C}$ for $30 \mathrm{~min}$ to afford a light yellow liquid in high yield ( $88 \%)$. The identity and purity of [Bmim] $\mathrm{Cl}$ obtained were analyzed by ${ }^{1} \mathrm{H}-\mathrm{NMR},{ }^{13} \mathrm{C}-\mathrm{NMR}$ and LC/MS spectroscopy. In continuation of the preparation of [Bmim] $\mathrm{Cl} \cdot 2 \mathrm{AlCl}_{3}$, an amount of aluminum chloride $(4 \mathrm{mmol}, 0.534 \mathrm{~g})$ was added slowly into a $10 \mathrm{~mL}$ round-bottom flask containing [Bmim] $\mathrm{Cl}(2 \mathrm{mmol}, 0.349 \mathrm{~g})$. After that, the reaction mixture were stirred magnetically at room temperature for $12 \mathrm{~h}$. The identity and purity of acidic catalyst, [Bmim]Cl-2 $\mathrm{AlCl}_{3}$, were checked by ${ }^{1} \mathrm{H}-\mathrm{NMR}$ and integrated as follows: ${ }^{1} \mathrm{H}-\mathrm{NMR}\left(500 \mathrm{MHz}, \mathrm{D}_{2} \mathrm{O}\right)$ : $\delta(\mathrm{ppm}) 8.65(\mathrm{~s}, 1 \mathrm{H}), 7.43(\mathrm{~s}, 1 \mathrm{H}), 7.38(\mathrm{~s}, 1 \mathrm{H}), 4.14(\mathrm{t}, J=7.0 \mathrm{~Hz}, 2 \mathrm{H}), 3.84(\mathrm{~s}, 3 \mathrm{H}), 1.77-1.82(\mathrm{~m}, 2 \mathrm{H})$, $1.23-1.30(\mathrm{~m}, 2 \mathrm{H}), 0.87(\mathrm{t}, J=7.5 \mathrm{~Hz}, 3 \mathrm{H})$.

\subsection{General Procedure for the Sulfinylation of Aromatic Compound with Sulfinic Ester under Ultrasound Irradiation}

An amount of sulfinic ester $(1 \mathrm{mmol}),[\mathrm{Bmim}]\left[\mathrm{Al}_{2} \mathrm{Cl}_{7}\right](1.2 \mathrm{mmol}, 0.530 \mathrm{~g})$ and aromatic compound $(1 \mathrm{mmol})$ were sequentially added into a test-tube $(\mathrm{d}=1.5 \mathrm{~cm}, \mathrm{~h}=16 \mathrm{~cm})$ sealed with its cap. The flask was placed into an ultrasound bath where the mixture of reactants was exposed to ultrasound irradiation for a specific period of time. Subsequently, the reaction mixture was extracted with ethyl acetate $(3 \times 15 \mathrm{~mL})$. The combined extracts were dried by anhydrous $\mathrm{Na}_{2} \mathrm{SO}_{4}$. After the removal of the solvent by rotary evaporation, the residue was purified by column chromatography using eluent as a mixture of $n$-hexane and ethyl acetate.

\subsection{Spectroscopic Data}

The identity and purity of all products reported were confirmed by ${ }^{1} \mathrm{H}-\mathrm{NMR},{ }^{13} \mathrm{C}-\mathrm{NMR}$, and LC/MS. The unknown NMR spectroscopic data are described below and well-known compounds (3g [45], 3i [32], 3i' [32], and 3k [32]) have been found compatible with those reported in the literature.

2,4-Dimethoxy-1-(phenylsulfinyl)benzene (3a). Light brown liquid, ${ }^{1} \mathrm{H}-\mathrm{NMR}\left(500 \mathrm{MHz}, \mathrm{CDCl}_{3}\right.$ ): $\delta(\mathrm{ppm}) 7.73(\mathrm{~d}, J=8.5 \mathrm{~Hz}, 1 \mathrm{H}), 7.66(\mathrm{dd}, J=2.0 \mathrm{~Hz}, J=8.0 \mathrm{~Hz}, 2 \mathrm{H}), 7.38-7.41(\mathrm{~m}, 3 \mathrm{H}), 6.62$ $(\mathrm{dd}, J=2.0 \mathrm{~Hz}, J=8.5 \mathrm{~Hz}, 1 \mathrm{H}), 6.39(\mathrm{~d}, J=2.0 \mathrm{~Hz}, 1 \mathrm{H}), 3.80(\mathrm{~s}, 3 \mathrm{H}), 3.77(\mathrm{~s}, 3 \mathrm{H}) .{ }^{13} \mathrm{C}-\mathrm{NMR}(125 \mathrm{MHz}$, $\mathrm{CDCl}_{3}$ ): $\delta$ (ppm) 163.53, 157.30, 146.01, 130.56, 128.87 (2C), 126.55, 125.04 (2C), 124.90, 105.70, 98.95, 55.69, 55.58. HRMS-ESI: $m / z$ [M + H] ${ }^{+}$calcd. for $\mathrm{C}_{14} \mathrm{H}_{14} \mathrm{SO}_{3}, 263.0736$; found, 263.0732 .

2,4-Dimethoxy-1-(ethylsulfinyl)benzene (3b). Light brown liquid, ${ }^{1} \mathrm{H}-\mathrm{NMR}\left(500 \mathrm{MHz}, \mathrm{CDCl}_{3}\right.$ ): $\delta(\mathrm{ppm}) 7.64(\mathrm{~d}, J=8.5 \mathrm{~Hz}, 1 \mathrm{H}), 6.67(\mathrm{dd}, J=8.5 \mathrm{~Hz}, J=2.5 \mathrm{~Hz}, 1 \mathrm{H}), 6.45(\mathrm{~d}, J=2.5 \mathrm{~Hz}, 1 \mathrm{H}), 3.84(\mathrm{~s}, 3 \mathrm{H})$, $3.83(\mathrm{~s}, 3 \mathrm{H}), 2.97-3.05(\mathrm{~m}, 1 \mathrm{H}), 2.73-2.81(\mathrm{~m}, 1 \mathrm{H}), 1.18(\mathrm{t}, J=7.5 \mathrm{~Hz}, 3 \mathrm{H}) \cdot{ }^{13} \mathrm{C}-\mathrm{NMR}\left(125 \mathrm{MHz}, \mathrm{CDCl}_{3}\right)$ : $\delta$ (ppm) 163.30, 156.36, 127.14, 121.74, 105.20, 98.77, 55.69, 55.61, 46.89, 5.64. HRMS-ESI: $m / z$ [M + H] calcd. for $\mathrm{C}_{10} \mathrm{H}_{14} \mathrm{SO}_{3}, 215.0736$; found, 215.0758 .

2,4-Dimethoxy-1-(2-propylsulfinyl)benzene (3c). Light brown liquid, ${ }^{1} \mathrm{H}-\mathrm{NMR}\left(500 \mathrm{MHz}, \mathrm{CDCl}_{3}\right)$ : $\delta(\mathrm{ppm}) 7.62(\mathrm{~d}, J=8.5 \mathrm{~Hz}, 1 \mathrm{H}), 6.66(\mathrm{dd}, J=8.5 \mathrm{~Hz}, J=2.0 \mathrm{~Hz}, 1 \mathrm{H}), 6.45(\mathrm{~d}, J=2.0 \mathrm{~Hz}, 1 \mathrm{H})$, $3.84(\mathrm{~s}, 3 \mathrm{H}), 3.83(\mathrm{~s}, 3 \mathrm{H}), 3.04-3.10(\mathrm{~m}, 1 \mathrm{H}), 1.35(\mathrm{~d}, J=7.0 \mathrm{~Hz}, 3 \mathrm{H}), 1.03(\mathrm{~d}, J=6.5 \mathrm{~Hz}, 3 \mathrm{H}) .{ }^{13} \mathrm{C}-\mathrm{NMR}$ 
$\left(125 \mathrm{MHz}, \mathrm{CDCl}_{3}\right): \delta$ (ppm) 163.27, 156.80, 127.72, 120.72, 105.17, 98.61, 55.60, 55.51, 51.23, 16.82, 12.72. HRMS-ESI: $m / z[\mathrm{M}+\mathrm{H}]^{+}$calcd. for $\mathrm{C}_{11} \mathrm{H}_{16} \mathrm{SO}_{3}, 229.0893$; found, 229.0907 .

2,4-Dimethoxy-1-(octylsulfinyl)benzene (3d). Light brown liquid, ${ }^{1} \mathrm{H}-\mathrm{NMR}$ (500 $\mathrm{MHz}, \mathrm{CDCl}_{3}$ ): $\delta(\mathrm{ppm}) 7.67(\mathrm{~d}, J=9.0 \mathrm{~Hz}, 1 \mathrm{H}), 6.67(\mathrm{dd}, J=8.5 \mathrm{~Hz}, J=2.0 \mathrm{~Hz}, 1 \mathrm{H}), 6.46(\mathrm{~d}, J=2.0 \mathrm{~Hz}, 1 \mathrm{H})$, $3.84(\mathrm{~s}, 6 \mathrm{H}), 2.94-2.98(\mathrm{~m}, 1 \mathrm{H}), 2.75-2.78(\mathrm{~m}, 1 \mathrm{H}), 1.79-1.82(\mathrm{~m}, 1 \mathrm{H}), 1.58-1.61(\mathrm{~m}, 1 \mathrm{H}), 1.24-1.29$ $(\mathrm{m}, 10 \mathrm{H}), 0.86(t, J=7.0 \mathrm{~Hz}, 3 \mathrm{H}) .{ }^{13} \mathrm{C}-\mathrm{NMR}\left(125 \mathrm{MHz}, \mathrm{CDCl}_{3}\right): \delta(\mathrm{ppm}) 163.31,156.36,126.84,122.46$, $105.35,98.81,55.72,55.63,54.13,31.75,29.15,29.03,28.68,22.59,21.97,14.04$. HRMS-ESI: $m / z[\mathrm{M}+\mathrm{H}]^{+}$ calcd. for $\mathrm{C}_{16} \mathrm{H}_{26} \mathrm{SO}_{3}, 299.1675$; found, 299.1675.

2,4-Dimethoxy-1-(p-tolylsulfinyl)benzene (3e). Light brown liquid, ${ }^{1} \mathrm{H}-\mathrm{NMR}$ (500 $\mathrm{MHz}, \mathrm{CDCl}_{3}$ ): $\delta(\mathrm{ppm}) 7.73(\mathrm{~d}, J=8.5 \mathrm{~Hz}, 1 \mathrm{H}), 7.54(\mathrm{~d}, J=8.5 \mathrm{~Hz}, 2 \mathrm{H}), 7.21(\mathrm{~d}, J=8.0 \mathrm{~Hz}, 2 \mathrm{H}), 6.63(\mathrm{dd}, J=2.5 \mathrm{~Hz}$, $J=8.5 \mathrm{~Hz}, 1 \mathrm{H}), 6.39(\mathrm{~d}, J=2.5 \mathrm{~Hz}, 1 \mathrm{H}), 3.80(\mathrm{~s}, 3 \mathrm{H}), 3.76(\mathrm{~s}, 3 \mathrm{H}), 2.34(\mathrm{~s}, 3 \mathrm{H}) .{ }^{13} \mathrm{C}-\mathrm{NMR}(125 \mathrm{MHz}$, $\left.\mathrm{CDCl}_{3}\right): \delta$ (ppm) 164.05, 157.82, 143.25, 141.64, 130.21 (2C), 127.06, 125.81 (2C), 125.48, 106.19, 99.54, 56.31, 56.20, 21.98. HRMS-ESI: $m / z[\mathrm{M}+\mathrm{H}]^{+}$calcd. for $\mathrm{C}_{15} \mathrm{H}_{16} \mathrm{SO}_{3}, 277.0893$; found, 277.0892.

2,4-Dimethoxy-1-((4-methoxyphenyl)sulfinyl)benzene (3f). Light brown liquid, ${ }^{1} \mathrm{H}-\mathrm{NMR}\left(500 \mathrm{MHz}, \mathrm{CDCl}_{3}\right)$ : $\delta(\mathrm{ppm}) 7.76(\mathrm{~d}, J=8.5 \mathrm{~Hz}, 1 \mathrm{H}), 7.58(\mathrm{dd}, J=7.0 \mathrm{~Hz}, J=2.0 \mathrm{~Hz}, 2 \mathrm{H}), 6.91(\mathrm{dd}, J=7.0 \mathrm{~Hz}, J=2.0 \mathrm{~Hz}$, $2 \mathrm{H}), 6.64(\mathrm{dd}, J=8.5 \mathrm{~Hz}, J=2.0 \mathrm{~Hz}, 1 \mathrm{H}), 6.39(\mathrm{~d}, J=2.0 \mathrm{~Hz}, 1 \mathrm{H}), 3.81(\mathrm{~s}, 3 \mathrm{H}), 3.80(\mathrm{~s}, 3 \mathrm{H}), 3.74$ (s, 3H). ${ }^{13} \mathrm{C}-\mathrm{NMR}\left(125 \mathrm{MHz}, \mathrm{CDCl}_{3}\right): \delta$ (ppm) 163.37, 161.60, 157.05, 137.11, 127.21 (2C), 126.24, 124.96, 114.36 (2C), 105.44, 98.95, 55.69, 55.59, 55.42. HRMS-ESI: $m / z$ [M+H] ${ }^{+}$calcd. for $\mathrm{C}_{15} \mathrm{H}_{26} \mathrm{SO}_{4}, 293.0842$; found, 293.0848.

1,2-Dimethoxy-4-(phenylsulfinyl)benzene (3h). Light brown liquid, ${ }^{1} \mathrm{H}-\mathrm{NMR}\left(500 \mathrm{MHz}, \mathrm{CDCl}_{3}\right)$ : $\delta$ (ppm) $7.59(\mathrm{dd}, J=1.5 \mathrm{~Hz}, J=8.0 \mathrm{~Hz}, 2 \mathrm{H}), 7.41-7.45(\mathrm{~m}, 3 \mathrm{H}), 7.19(\mathrm{dd}, J=2.0 \mathrm{~Hz}, J=8.0 \mathrm{~Hz}, 1 \mathrm{H}), 7.13$ $(\mathrm{d}, J=2.0 \mathrm{~Hz}, 1 \mathrm{H}), 6.89(\mathrm{~d}, J=8.5 \mathrm{~Hz}, 1 \mathrm{H}), 3.86(\mathrm{~s}, 3 \mathrm{H}), 3.84(\mathrm{~s}, 3 \mathrm{H}) .{ }^{13} \mathrm{C}-\mathrm{NMR}\left(125 \mathrm{MHz}, \mathrm{CDCl}_{3}\right)$ : $\delta$ (ppm) 151.79, 150.19, 145.97, 137.13, 130.88, 129.30 (2C), 124.70 (2C), 118.99, 111.21, 107.39, 56.22, 56.19. HRMS-ESI: $m / z$ [M $+\mathrm{H}]^{+}$calcd. for $\mathrm{C}_{14} \mathrm{H}_{14} \mathrm{SO}_{3}, 263.0736$; found, 263.0764 .

N,N-Dimethyl-4-(phenylsulfinyl)aniline (3j). White solid, m.p. $130-131{ }^{\circ} \mathrm{C}[46],{ }^{1} \mathrm{H}-\mathrm{NMR}(500 \mathrm{MHz}$, DMSO): $\delta(\mathrm{ppm}) 7.62(\mathrm{dd}, J=1.5 \mathrm{~Hz}, J=8.0 \mathrm{~Hz}, 2 \mathrm{H}), 7.42-7.50(\mathrm{~m}, 5 \mathrm{H}), 6.70(\mathrm{dd}, J=2.0 \mathrm{~Hz}, J=7.0 \mathrm{~Hz}$, 2H), 3.01 (s, 6H). ${ }^{13} \mathrm{C}-\mathrm{NMR}$ (125 MHz, DMSO): $\delta$ (ppm) 152.54, 146.38, 130.93, 130.30, 129.07 (2C), 127.83 (2C), 124.71 (2C), 112.08 (2C), 40.21 (2C). HRMS-ESI: $m / z$ [M + H] $]^{+}$calcd. for $\mathrm{C}_{14} \mathrm{H}_{15} \mathrm{NSO}, 246.0947$; found, 246.0946 .

2-Methoxy-1-(phenylsulfinyl)napthalene (31). White solid, m.p. 100-101 ${ }^{\circ} \mathrm{C}$ [47], ${ }^{1} \mathrm{H}-\mathrm{NMR}(500 \mathrm{MHz}$, $\left.\mathrm{CDCl}_{3}\right): \delta(\mathrm{ppm}) 8.70(\mathrm{dd}, J=8.5 \mathrm{~Hz}, J=1.0 \mathrm{~Hz}, 1 \mathrm{H}), 7.96(\mathrm{~d}, J=9.5 \mathrm{~Hz}, 1 \mathrm{H}), 7.78(\mathrm{dt}, J=8.0 \mathrm{~Hz}$, $J=1.0 \mathrm{~Hz}, 1 \mathrm{H}), 7.64(\mathrm{dd}, J=1.0 \mathrm{~Hz}, J=8.5 \mathrm{~Hz}, 2 \mathrm{H}), 7.45-7.49(\mathrm{~m}, 1 \mathrm{H}), 7.35-7.42(\mathrm{~m}, 4 \mathrm{H}), 7.28$ $(\mathrm{d}, J=9.0 \mathrm{~Hz}, 1 \mathrm{H}), 3.96(\mathrm{~s}, 3 \mathrm{H})[47] .{ }^{13} \mathrm{C}-\mathrm{NMR}\left(125 \mathrm{MHz}, \mathrm{CDCl}_{3}\right): \delta$ (ppm) 157.52, 145.26, 134.96, $131.99,129.72,129.64,128.83$ (2C), 128.79, 128.21, 124.65, 124.48 (2C), 123.74, 123.26, 113.32, 57.10. MS $\left(\mathrm{C}_{17} \mathrm{H}_{14} \mathrm{SO}_{2}\right): m / z=282[\mathrm{M}]^{+}, 266,234,127,77$.

1-Methyl-3-(phenylsulfinyl)indole (3m). White solid, m.p. 120-120.5 ${ }^{\circ} \mathrm{C}[48],{ }^{1} \mathrm{H}-\mathrm{NMR}$ (500 MHz, DMSO): $\delta(\mathrm{ppm}) 8.10(\mathrm{~s}, 1 \mathrm{H}), 7.64(\mathrm{dd}, J=1.5 \mathrm{~Hz}, J=8.0 \mathrm{~Hz}, 2 \mathrm{H}), 7.50-7.54(\mathrm{~m}, 3 \mathrm{H}), 7.46(\mathrm{tt}, J=7.0 \mathrm{~Hz}, J=1.0 \mathrm{~Hz}$, $1 \mathrm{H}), 7.25(\mathrm{dd}, J=8.0 \mathrm{~Hz}, J=1.0 \mathrm{~Hz}, 1 \mathrm{H}), 7.22(\mathrm{td}, J=8.0 \mathrm{~Hz}, J=1.0 \mathrm{~Hz}, 1 \mathrm{H}), 7.01(\mathrm{td}, J=8.0 \mathrm{~Hz}$, $J=1.0 \mathrm{~Hz}, 1 \mathrm{H}), 3.85(\mathrm{~s}, 3 \mathrm{H})[48] .{ }^{13} \mathrm{C}-\mathrm{NMR}(125 \mathrm{MHz}, \mathrm{DMSO}): \delta$ (ppm) 144.91, 137.56, 134.15, 129.99, 128.99 (2C), 124.39 (2C), 123.58, 122.85, 120.90, 119.05, 115.33, 111.14, 33.02. HRMS-ESI: $m / z$ [M + H] ${ }^{+}$ calcd. for $\mathrm{C}_{15} \mathrm{H}_{13} \mathrm{NSO}, 256.0791$; found, 256.0782 .

3-(Phenylsulfinyl)indole (3n). White solid, m.p. $126-127^{\circ} \mathrm{C}[48],{ }^{1} \mathrm{H}-\mathrm{NMR}(500 \mathrm{MHz}, \mathrm{DMSO}): \delta$ (ppm) $11.93(\mathrm{~s}, 1 \mathrm{H}), 8.11(\mathrm{~d}, J=3.0 \mathrm{~Hz}, 1 \mathrm{H}), 7.63-7.66(\mathrm{~m}, 2 \mathrm{H}), 7.50-7.54(\mathrm{~m}, 3 \mathrm{H}), 7.44-7.48(\mathrm{~m}, 2 \mathrm{H}), 7.23$ $(\mathrm{d}, J=8.0 \mathrm{~Hz}, 1 \mathrm{H}), 7.15(\mathrm{td}, J=8.0 \mathrm{~Hz}, J=1.0 \mathrm{~Hz}, 1 \mathrm{H}), 6.94-6.97(\mathrm{~m}, 1 \mathrm{H})$ [47]. ${ }^{13} \mathrm{C}-\mathrm{NMR}(125 \mathrm{MHz}$, DMSO): $\delta$ (ppm) 144.98, 137.06, 130.81, 129.95, 128.99 (2C), 124.42 (2C), 123.18, 122.85, 120.66, 119.00, 116.33, 112.71. HRMS-ESI: $m / z$ [M + H] ${ }^{+}$calcd. for $\mathrm{C}_{14} \mathrm{H}_{11} \mathrm{NSO}, 242.0634$; found, 242.0634 . 
2-(Phenylsulfinyl)dibenzo[b,d]thiophene (3p). White solid, ${ }^{1} \mathrm{H}-\mathrm{NMR}\left(500 \mathrm{MHz}, \mathrm{CDCl}_{3}\right): \delta(\mathrm{ppm}) 8.55$ $(\mathrm{d}, J=1.0 \mathrm{~Hz}, 1 \mathrm{H}), 8.22-8.24(\mathrm{~m}, 1 \mathrm{H}), 7.90(\mathrm{~d}, J=8.0 \mathrm{~Hz}, 1 \mathrm{H}), 7.85-7.87(\mathrm{~m} 1 \mathrm{H}), 7.71(\mathrm{dd}, J=8.0 \mathrm{~Hz}$, $J=1.5 \mathrm{~Hz}, 2 \mathrm{H}), 7.59(\mathrm{dd}, J=8.5 \mathrm{~Hz}, J=1.5 \mathrm{~Hz}, 1 \mathrm{H}), 7.51-7.52(\mathrm{~m}, 2 \mathrm{H}), 7.44-7.47(\mathrm{~m}, 3 \mathrm{H}) .{ }^{13} \mathrm{C}-\mathrm{NMR}$ $\left(125 \mathrm{MHz}, \mathrm{CDCl}_{3}\right)$ and HSQC: $\delta(\mathrm{ppm}) 145.77,142.46,141.88,139.89,136.21,134.69,131.17,129.43$ (2C), 127.63, 124.93 (3C), 123.75, 122.94, 122.66, 122.15, 118.19. HRMS-ESI: $m / z$ [M + H] ${ }^{+}$calcd. for $\mathrm{C}_{18} \mathrm{H}_{12} \mathrm{~S}_{2} \mathrm{O}$, 309.0402; found: 309.0403 .

2-(Phenylsulfinyl)-9H-fluorene (3q). White solid, ${ }^{1} \mathrm{H}-\mathrm{NMR}\left(500 \mathrm{MHz}, \mathrm{CDCl}_{3}\right): \delta(\mathrm{ppm}) 7.82-7.85(\mathrm{~m}, 2 \mathrm{H})$, $7.78(\mathrm{~d}, J=7.0 \mathrm{~Hz}, 1 \mathrm{H}), 7.67-7.70(\mathrm{~m}, 2 \mathrm{H}), 7.65(\mathrm{dd}, J=8.0 \mathrm{~Hz}, J=2.0 \mathrm{~Hz}, 1 \mathrm{H}), 7.55(\mathrm{~d}, J=7.5 \mathrm{~Hz}, 1 \mathrm{H})$, $7.41-7.49(\mathrm{~m}, 3 \mathrm{H}), 7.38(\mathrm{td}, J=7.5 \mathrm{~Hz}, J=1.0 \mathrm{~Hz}, 1 \mathrm{H}), 7.35(\mathrm{td}, J=7.5 \mathrm{~Hz}, J=1.5 \mathrm{~Hz}, 1 \mathrm{H}), 3.91(\mathrm{~s}, 1 \mathrm{H})$. ${ }^{13} \mathrm{C}-\mathrm{NMR}\left(125 \mathrm{MHz}, \mathrm{CDCl}_{3}\right)$ : $\delta$ (ppm) 146.03, 145.08, 144.50, 143.86, 143.71, 140.42, 131.06, 129.45 (2C), 128.03, 127.20, 125.34, 124.90 (2C), 124.26, 121.63, 120.67, 120.56, 37.06. HRMS-ESI: $m / z$ [M + H] ${ }^{+}$calcd. for $\mathrm{C}_{19} \mathrm{H}_{14} \mathrm{SO}$, 291.0838; found, 291.0839 .

\section{Conclusions}

An efficient, highly regio-selective and green synthetic method to prepare sulfoxides has been developed. Sulfinic esters appeared as greener, safer, and more stable electrophiles than sulfinyl chlorides in order to improve the reaction process at room temperature instead of very low temperature. [Bmim $] \mathrm{Cl} \cdot 2 \mathrm{AlCl}_{3}$ is found out to be a better acidic catalyst owing to its efficiency, easy operation and recyclability. Moreover, ultrasound irradiation has good effects on the yields of sulfoxide products within a shorter reaction time.

Supplementary Materials: Supplementary materials are available online. ${ }^{1} \mathrm{H}-\mathrm{NMR}$ and ${ }^{13} \mathrm{C}-\mathrm{NMR}$ of unknown products.

Acknowledgments: The authors are grateful to the Vietnam National University of Ho Chi Minh City (VNU-HCM) for financial support (Grant number C2015-18-12).

Author Contributions: T.X.T.L. conceived, designed the experiments and wrote the paper; N.-L.T.N. and H.-T.V. performed the experiments and analyzed the data; and F.D. contributed reagents/materials/analysis tools and wrote the paper.

Conflicts of Interest: The authors declare no conflict of interest.

\section{References}

1. Carreno, M.C. Applications of sulfoxides to asymmetric synthesis of biologically active compounds. Chem. Rev. 1995, 95, 1717-1760. [CrossRef]

2. Schmied, R.; Wang, G.-X.; Korth, M. Intracellular $\mathrm{Na}^{+}$activity and positive inotropic effect of sulmazole in guinea pig ventricular myocardium. Circ. Res. 1991, 68, 597-604. [CrossRef] [PubMed]

3. Zifko, U.A.; Rupp, M.; Schwarz, S.; Zipko, H.T.; Maida, E.M. Modafinil in treatment of fatigue in multiple sclerosis. J. Neurol. 2002, 249, 983-987. [CrossRef] [PubMed]

4. Nieves, A.V.; Lang, A.E. Treatment of excessive daytime sleepiness in patients with Parkinson's disease with modafinil. Clin. Neuropharmacol. 2002, 25, 111-114. [CrossRef] [PubMed]

5. Padmanabhan, S.; Lavin, R.C.; Durant, G.J. Asymmetric synthesis of a neuroprotective and orally active $N$-methyl-D-aspartate receptor ion-channel blocker, CNS 5788. Tetrahedron Asymmetry 2000, 11, 3455-3457. [CrossRef]

6. McTavish, D.; Buckley, M.M.-T.; Heel, R.C. Omeprazole: An updated review of its pharmacology and therapeutic use in acid-related disorders. Drugs 1991, 42, 138-170. [CrossRef] [PubMed]

7. Richardson, P.; Hawkey, C.J.; Stack, W.A. Proton pump inhibitors. Pharmacology and rationale for use in gastrointestinal disorder. Drugs 1998, 56, 307-335. [CrossRef] [PubMed]

8. Spencer, C.M.; Faulds, D. Esomeprazole. Drugs 2000, 60, 321-329. [CrossRef] [PubMed]

9. Okabe, S.; Shimosako, K.; Amagase, K. Pharmacological regulation of gastric acid secretion in the apical membrane of parietal cells; a new target for antisecretory drugs. J. Physiol. Pharmacol. 2001, 52, 639-656. [PubMed]

10. Baker, D.E. New drug review: Esomeprazole magnesium (Nexium). Rev. Gastrolenterol. Disord. 2001, 1, 32-41. 
11. Salas, M.; Ward, A.; Caro, J. Are proton pump inhibitors the first choice for acute treatment of gastric ulcers? A meta analysis of randomized clinical trials. BMC Gastroenterol. 2002, 2, 17. [CrossRef]

12. Lai, K.C.; Lam, S.K.; Chu, K.M.; Wong, B.C.Y.; Hui, W.M.; Hu, W.H.C.; Lau, G.K.K.; Wong, W.M.; Yuen, M.F.; Chan, A.O.O.; et al. Lansoprazole for the prevention of recurrences of ulcer complications from long-term low-dose aspirin use. N. Engl. J. Med. 2002, 346, 2033-2038. [CrossRef] [PubMed]

13. Adetumbi, M.A.; Lau, B.H.S. Allium sativum (garlic)-A natural antibiotic. Med. Hypotheses 1983, 12, $227-237$. [CrossRef]

14. Yoshida, S.; Kasuga, S.; Hayashi, N.; Ushiroguchi, T.; Matsuura, H.; Nakagawa, S. Antifungal activity of ajoene derived from garlic. Appl. Environ. Microbiol. 1987, 53, 615-617. [PubMed]

15. Focke, M.; Feld, A.; Lichtenthaler, H.K. Allicin-A naturally occurring antibiotic from garlic, specifically inhibits acetyl-CoA synthetase. FEBS Lett. 1990, 261, 106-108. [CrossRef]

16. Agarwal, K.C. Therapeutic actions of garlic constituents. Med. Res. Rev. 1996, 16, 111-124. [CrossRef]

17. Pérez-Giraldo, C.; Cruz-Villalón, G.; Sánchez-Silos, R.; Martínez-Rubio, R.; Blanco, M.T.; Gómez-García, A.C. In vitro activity of allicin against Staphylococcus epidermidis and influence of subinhibitory concentrations on biofilm formation. J. Appl. Microbiol. 2003, 95, 709-711. [CrossRef] [PubMed]

18. Kotelanski, B.; Grozmann, R.J.; Cohn, J.N. Positive inotropic effect of oral esproquin in normal subjects. Clin. Pharmacol. Ther. 1973, 14, 427-433. [CrossRef] [PubMed]

19. Kowalski, P.; Mitka, K.; Ossowska, K.; Kolarska, Z. Oxidation of sulfides to sulfoxides. Part 1: Oxidation using halogen derivatives. Tetrahedron 2005, 61, 1933-1953. [CrossRef]

20. Kaczorowska, K.; Kolarska, Z.; Mitka, K.; Kowalski, P. Oxidation of sulfides to sulfoxides. Part 2: Oxidation by hydrogen peroxide. Tetrahedron 2005, 61, 8315-8327. [CrossRef]

21. Still, I.W.J.; Ablenas, F.J. Conversion of sulfones to sulfoxides via hydride reduction of (aryloxy)sulfoxonium salt intermediates. J. Org. Chem. 1983, 48, 1617-1620. [CrossRef]

22. Andersen, K.K. Synthesis of (+)-ethyl p-tolyl sulfoxide from (-)-menthyl (-)-p-toluenesulfinate. Tetrahedron Lett. 1962, 3, 93-95. [CrossRef]

23. Andersen, K.K.; Gaffield, W.; Papanikolaou, N.E.; Foley, J.W.; Perkins, R.I. Optically active sulfoxides. The synthesis and rotatory dispersion of some diaryl sulfoxides. J. Am. Chem. Soc. 1964, 86, 5637-5646. [CrossRef]

24. Capozzi, M.A.M.; Cardellicchio, C.; Naso, F. Enantioselective routes to sulfoxides based upon the use of carbanionic leaving groups. Eur. J. Org. Chem. 2004, 1855-1865. [CrossRef]

25. Mohile, S.S.; Potdar, M.K.; Salunkhe, M.M. An ionic liquid-mediated expeditious route to the syntheses of diaryl sulfoxides. Tetrahedron Lett. 2003, 44, 1255-1258. [CrossRef]

26. Yadav, J.S.; Reddy, B.V.S.; Rao, R.S.; Kumar, S.P.; Nagaiah, K. Scandium triflate catalyzed one-pot synthesis of diaryl sulfoxides. Synlett 2002, 5, 784-786. [CrossRef]

27. Schöberl, A.; Wagner, A. Herstellung und Umwandlungvon Sulfoxydenund Sulfiniminen. In Houben-Weyl, 4th ed.; Müller, E., Ed.; Thieme: Stuggart, Germany, 1955; p. 217.

28. Replogle, L.L.; Maynard, J.R. Organosulfur derivatives of azulene. II. 1-Azulyl sulfoxides and sulfones. J. Org. Chem. 1967, 32, 1909-1915. [CrossRef]

29. Douglass, I.B.; Farah, B.S. Some reactions of methanesulfinyl chloride. J. Org. Chem. 1958, $23,805-807$. [CrossRef]

30. Fujisawa, T.; Kakutani, M.; Kobayashi, N. On the reaction of $p$-toluenesulfinyl chloride with anisole. Bull. Chem. Soc. Jpn. 1973, 46, 3615-3617. [CrossRef]

31. Olah, G.A.; Nishimura, J. Aromatic substitution. XXXII. Aluminum chloride catalyzed arenesulfinylation of benzene and toluene with benzenesulfinyl and substituted benzenesulfinyl chlorides in nitromethane solution. J. Org. Chem. 1974, 39, 1203-1205. [CrossRef]

32. Yuste, F.; Linares, A.H.; Mastranzo, V.M.; Ortiz, B.; Sánchez-Obregón, R.; Fraile, A.; Ruano, J.L.G. Methyl sulfinates as electrophiles in Friedel-Crafts reactions. Synthesis of aryl sulfoxides. J. Org. Chem. 2011, 76, 4635-4644. [CrossRef] [PubMed]

33. Jung, M.E.; Lazarova, T.I. Preparation of (phenylsulfinyl)phenols from aryl phenylsulfinates: “Thia-Fries rearrangement". Tetrahedron Lett. 1996, 37, 7-8. [CrossRef]

34. Sugden, S.; Wilkins, H. CLXVII.-The parachor and chemical constitution. Part XII. Fused metals and salts. J. Chem. Soc. 1929, 1291-1298. [CrossRef]

35. Wassercheid, P.; Keim, W. Ionic liquid-New "solutions" for transition metal catalysis. Angew. Chem. Int. Ed. 2000, 39, 3772-3789. [CrossRef] 
36. Welton, I. Room-temperature ionic liquids. Solvents for synthesis and catalysis. Chem. Rev. 1999, 99, 2071-2083. [CrossRef] [PubMed]

37. Boon, J.A.; Levinsky, J.A.; Pflug, J.I.; Wilkes, J.S. Friedel-Crafts reactions in ambient-temperature molten salts. J. Org. Chem. 1986, 51, 480-483. [CrossRef]

38. Mason, T.J.; Lorimer, J.P. Sonochemistry: Theory, Applications and Uses of Ultrasound in Chemistry; Ellis Horwood: West Sussex, UK, 1988; pp. 74-98.

39. Luche, J.-L. Synthetic Organic Sonochemistry; Plemum Press: New York, NY, USA, 1998; pp. $246-263$.

40. Seddon, K.R.J. Ionic liquids for clean technology. J. Chem. Technol. Biotechnol. 1997, 68, 351-356. [CrossRef]

41. Tillett, J.G. Nucleophilic substitution at tricoordinate sulfur. Chem. Rev. 1976, 76, 747-772. [CrossRef]

42. Nara, S.J.; Harjani, J.R.; Salunkhe, M.M. Friedel-Crafts sulfonylation in 1-butyl-3-methylimidazolium chloroaluminate ionic liquids. J. Org. Chem. 2001, 66, 8616-8620. [CrossRef] [PubMed]

43. Miao, T.; Li, P.; Zhang, Y.; Wang, L. A sulfenylation reaction: Direct synthesis of 3-arylsulfinylindoles from arylsulfinic acids and indoles in water. Org. Lett. 2015, 17, 832-835. [CrossRef] [PubMed]

44. Nguyen, L.-A.T.; Le, N.T.; Chau, T.-P.; Duus, F.; Luu, T.X.T. “One pot” synthesis of sulfinic esters from ultrasound irradiation accelerated tanderm reaction of thiols and alcohols with $N$-Bromosuccinimide. Manuscript in Preparation.

45. Furukawa, N.; Ogawa, S.; Matsumara, K.; Fujihara, H. Extremely facile ligand-exchange and disproportionation reactions of diaryl sulfoxides, selenoxides, and triarylphosphine oxides with organolithium and Grignard reagents. J. Org. Chem. 1991, 56, 6341-6348. [CrossRef]

46. Oae, S.; Yamada, O.; Maeda, T. The reaction of sulfinic acids with N,N-dimethylaniline. Bull. Chem. Soc. Jpn. 1974, 47, 166-169. [CrossRef]

47. Bell, K.H.; McCaffery, L.F. Use of menthyl 2-methoxynaphthalene1-1-sulfinates in the Andersen synthesis of optically active sulfoxides. Facile cleavage by Grignard reagents of some aromatic methyl ethers. Aust. J. Chem. 1994, 47, 1925. [CrossRef]

48. Garcia, J.; Ortiz, C.; Greenhouse, R. The regiospecific Pummerer-like introduction of chlorine atoms into pyrrol-3-yl and indol-3-yl sulfoxides. J. Org. Chem. 1988, 53, 2634-2637. [CrossRef]

Sample Availability: Not available.

(c) 2017 by the authors. Licensee MDPI, Basel, Switzerland. This article is an open access article distributed under the terms and conditions of the Creative Commons Attribution (CC BY) license (http://creativecommons.org/licenses/by/4.0/). 